\title{
Line Balancing Techniques for Efficiency Improvement in Construction Steel Company
}

\author{
Farida Pulansari* , Yoga Aulia Sulaiman, Restu
}

Department of Industrial Engineering, Faculty of Engineering, Universitas Pembangunan Nasional "Veteran” Surabaya, East Java, Indonesia

* Corresponding author

E-mail:

pulansari@gmail.com

\begin{abstract}
$\mathrm{XYZ}$ company is a company engaged in steel construction. This company produces steel construction with several classifications, namely Building Construction (structure) and Mining Construction (Conveyor and Tank). This problem is found in the production process area where the efficiency of the company is not optimal because of the bottleneck between workstations. To increase efficiency and reduce bottlenecks, companies use the Largest Candidate Rule (LCR); Killbridge and the Western Method (KWM); and the Ranked Positional Weights (RPW) Method. After comparing the three methods, LCR has the best results. Production line efficiency is $92.2 \%$, balance delay is $7.8 \%$, and the smoothness index is 14.6 with 11 operators.
\end{abstract}

Keywords: Line balancing, largest candidate rule, killbridge and western method, ranked positional weights.

\section{Introduction}

The production process is an activity that involves manpower of materials, as well as equipment to produce useful products (Assauri, 2016). Intense competition between the manufacturing industry and consumer demand that continues to increase every year requires companies to improve the performance of the production process carried out. The performance of the production process can be seen from the resulting efficiency. unbalanced production lines will lead to less than maximum company efficiency and increase bottlenecks, resulting in large waiting times and a buildup of semifinished goods at several work stations. Track balance puts pressure on the assignment of individual work elements to the work station so that human resources have the same quantity of work (Yudha, 2017). PT. XYZ is a company engaged in the field of steel construction. This company produces steel construction with several classifications, namely construction of buildings (structures) and Mining Construction.

According to Nasution (2009), the problem of track balance mostly occurs in the assembly process than in the manufacturing process. This is as happened to PT.XYZ. Also, the problem that occurs is that the company's efficiency is not optimal, so there is a bottleneck and there needs to be a solution, one of which is by balancing the trajectory to improve company efficiency. From the problems that have been described, the purpose of this study is to improve efficiency and reduce bottlenecks on the production line to get the results of grouping tasks with balanced capacity. This research was conducted by carrying out the work measurement process by measuring the processing

How to cite:

Pulansari, F., Sulaiman, Y. A. S., \& Restu. (2020). Line balancing techniques for efficiency improvement in construction steel company. $1^{\text {st }}$ International Conference Eco-Innovation in Science, Engineering, and Technology. NST Proceedings. pages 221-225. doi: 10.11594/ nstp.2020.0535 
time of the operation. Data is collected using time studies and determine time standards. The alternative used to evaluate production line performance is to compare heuristic methods ((Hackman, et. al., 1989 in Kriengkorakot \& Pianthong, 2015). The production line balancing method used is the Largest Candidate Rule (LCR), Killbridge, and Western Method (KWM), and Ranged Positional Weight (RPW) with the maximum results will be used as a suggestion for the existing problems. Line balancing is balancing the assignment of task elements from an assembly line to the work stations. Its main function is to minimize the number of work stations and minimize the total idle time price at all stations for a certain output level (Gaspersz, 2009; Henky, et al., 2016).

\section{Research Method}

In conducting research, problem-solving steps need to be done. Following the steps in solving this research problem.

1. Data collection

Collecting research data The data includes production capacity data, available work station data, cycle time data for each work station, and precedence diagram data, raw material data.

2. Data Uniformity Test

Test the uniformity of data to ensure that the data collected is from the same system, and separates data that has different characteristics. According to Syukron (2014) measurement of work, elements is done by using a stopwatch

3. Data Adequacy Test

Testing the adequacy of the data to determine the number of samples taken is sufficient to be processed or not, and has been able to represent the existing system.

4. Data processing

Line Balancing Calculations. By making an Assembly Chart (AC) then calculating the standard time for each process station. Draw a precedence diagram. calculate the performance of the proposed assembly line formed after the use of the line balancing method (Panchal, 2017).

5. Company Performance.

Perform performance calculations that are running on the company today.

6. Largest Candidate Rule

Perform calculations with the rules in the Largest Candidate Rule method

7. Killbridge and Wester Method

Perform calculations with the rules in the Killbridge and Wester Method

8. Ranked Positional Weights

Perform calculations with the rules in the Ranking Positional Weights method (Niaz \& Kazi, 2014)

9. Selection of the Most Optimal Results Method

\section{Result and Discussion \\ Data collection}

In conducting this research, we need some data that will support solving the line balancing problem. Data obtained based on research and interviews at the company. To make one product, the company has 73 work elements. Among others: Cutting, Drilling, Testing, Welding, Cleaning, and Painting Process. The assembly chart shows in Table 1. 
Table 1. Assembly chart of the steel column production process

\begin{tabular}{|c|c|c|c|c|c|c|c|}
\hline No & Type of work/pieces & Pre. & Time & No & Type of work/pieces & Pre & Time \\
\hline 1 & $\begin{array}{l}\text { Cutting H } 400 * 200 * 8 * 13 \\
\text { (part A) 1p }\end{array}$ & - & 1,2 & 38 & $\begin{array}{l}\text { Component dimension } \\
\text { Test E }\end{array}$ & 5,24 & 1.9 \\
\hline 2 & $\begin{array}{l}\text { Cutting plate } 12 * 300 \text { (part B) } \\
\qquad 4 \mathrm{p}\end{array}$ & - & 0.6 & 39 & $\begin{array}{c}\text { Component dimension } \\
\text { test } \mathrm{F}\end{array}$ & 6 & 2.6 \\
\hline 3 & $\begin{array}{c}\text { Cutting Plate } 28 * 290(\text { Part C) } \\
1 \mathrm{p}\end{array}$ & - & 0.8 & 40 & $\begin{array}{c}\text { Component dimension } \\
\text { Test G }\end{array}$ & 7 & 2,9 \\
\hline 4 & Plate Cutting $9 * 45$ (part D) $4 p$ & - & 0.3 & 41 & $\begin{array}{l}\text { Test the dimensions of } \\
\text { Component } \mathrm{H}\end{array}$ & 8.25 & 1.6 \\
\hline 5 & $\begin{array}{l}\text { Plate Cutting } 10 * 180 \text { (part E) } \\
1 \mathrm{p}\end{array}$ & - & 0.5 & 42 & $\begin{array}{l}\text { Test for Component I } \\
\text { dimensions }\end{array}$ & 9.26 & 1.8 \\
\hline 6 & Cutting Plate $9 * 96$ (part F) 6p & - & 0.3 & 43 & $\begin{array}{c}\text { Component dimension } \\
\text { Test J }\end{array}$ & 10 & 2.8 \\
\hline 7 & Cutting plate $12 * 96$ (part G) $4 p$ & - & 0.4 & 44 & $\begin{array}{l}\text { Dimension Test } \\
\text { Component K }\end{array}$ & 11.27 & 1.6 \\
\hline 8 & $\begin{array}{l}\text { Cutting plate } 16 * 230(\text { part } \mathrm{H}) \\
1 \mathrm{p}\end{array}$ & - & 0.7 & 45 & $\begin{array}{l}\text { Test for Component } \mathrm{L} \\
\text { dimensions }\end{array}$ & 12.28 & 1.7 \\
\hline 9 & $\begin{array}{l}\text { Cutting plate } 12 * 186 \text { (part I) } \\
\qquad 1 \mathrm{p}\end{array}$ & - & 0.5 & 46 & $\begin{array}{l}\text { Test the dimensions of } \\
\text { Component } \mathrm{M}\end{array}$ & 13 & 2.7 \\
\hline 10 & Cutting plate $9 * 96$ (part J) $4 p$ & - & 0.3 & 47 & $\begin{array}{c}\text { Component dimension } \\
\text { Test } \mathrm{N}\end{array}$ & 14.29 & 1.9 \\
\hline 11 & Cutting plate $9 * 186$ (part K) 1 p & - & 0.4 & 48 & $\begin{array}{l}\text { Component O Test } \\
\text { dimensions }\end{array}$ & 15.30 & 1.6 \\
\hline 12 & $\begin{array}{l}\text { Cutting plate } 12 * 180 \text { (part L) } \\
\qquad 1 \mathrm{p}\end{array}$ & - & 0.5 & 49 & $\begin{array}{l}\text { Test the dimensions of } \\
\text { Component } \mathrm{P}\end{array}$ & 10,49 & 1.7 \\
\hline 13 & Cutting plate $9 * 96$ (part M) 4p & - & 0.3 & 50 & $\begin{array}{l}\text { Test component } \\
\text { dimensions } Q\end{array}$ & 17.31 & 1.6 \\
\hline 14 & $\begin{array}{c}\text { Cutting plate } 9 * 186(\text { part } N) \\
1 \mathrm{p}\end{array}$ & - & 0.4 & 51 & $\begin{array}{l}\text { Test for Component } \mathrm{R} \\
\text { dimensions }\end{array}$ & 18.32 & 1.8 \\
\hline 15 & $\begin{array}{l}\text { Cutting plate } 12 * 180 \text { (part 0) } \\
\qquad 1 \mathrm{p}\end{array}$ & - & 0.5 & 52 & $\begin{array}{c}\text { Component Dimension } \\
\text { Test S }\end{array}$ & 19 & 1.7 \\
\hline 16 & Cutting plate $9 * 96$ (part P) $2 p$ & - & 0.3 & 53 & $\begin{array}{l}\text { Test the dimensions of } \\
\text { the Component } \mathrm{T}\end{array}$ & 20 & 1.6 \\
\hline 17 & $\begin{array}{l}\text { Cutting plate } 12 * 180 \text { (part } Q) \\
1 \mathrm{p}\end{array}$ & - & 0.5 & 54 & $\begin{array}{l}\text { Test the U Component } \\
\text { dimensions }\end{array}$ & 21 & 1.8 \\
\hline 18 & Cutting plate $9 * 186($ part R) 1 p & - & 0.4 & 55 & $\begin{array}{l}\text { Test for Component V } \\
\text { dimensions }\end{array}$ & 22.33 & 1.7 \\
\hline 19 & Cutting plate $9 * 96$ (part S) $2 p$ & - & 0.3 & 56 & $\begin{array}{l}\text { Welding A, B, C, D (Part } \\
\text { 1) }\end{array}$ & $\begin{array}{l}34,35 \\
36,37\end{array}$ & 17.3 \\
\hline 20 & $\begin{array}{l}\text { Cutting plate } 12 * 180 \text { (part T) } \\
\qquad 1 \mathrm{p}\end{array}$ & - & 0.5 & 57 & Welding Test (1) & 56 & 11.2 \\
\hline 21 & Cutting plate $6^{*} 96$ (part U) $2 p$ & - & 0.2 & 58 & Welding E, F ex 1 (Part 2) & 38.39 & 13.7 \\
\hline 22 & $\begin{array}{l}\text { Cutting plate } 16 * 347 \text { (part V) } \\
\qquad 1 \mathrm{p}\end{array}$ & - & 0.9 & 59 & Welding Test (2) & 58 & 11.3 \\
\hline 23 & Drilling A 42 Holes & 1 & 5.6 & 60 & Welding G, H, I (part 3) & $\begin{array}{l}40,41 \\
42\end{array}$ & 11.8 \\
\hline 24 & Drilling E 10 Holes diameter 25 & 5 & 0.5 & 61 & Welding Test (3) & 60 & 9.2 \\
\hline 25 & Drilling H 8 hole diameter 25 & 8 & 0.8 & 62 & Welding J, K, L (part 4) & $\begin{array}{l}43,44 \\
45\end{array}$ & 11.7 \\
\hline 26 & Drilling I 5 hole diameter 25 & 9 & 0.4 & 63 & Welding Test (4) & 62 & 8.9 \\
\hline
\end{tabular}




\begin{tabular}{|c|c|c|c|c|c|c|c|}
\hline 27 & Drilling K 3 hole diameter 22 & 11 & 0.2 & 64 & Welding M, N, O (part 5) & $\begin{array}{c}46,47 \\
48\end{array}$ & 11.6 \\
\hline 28 & Drilling L 8 hole diameter 25 & 12 & 0.6 & 65 & Welding Test (5) & 64 & 9.3 \\
\hline 29 & Drilling N 3 hole diameter 22 & 14 & 0.2 & 66 & Welding $\mathrm{P}, \mathrm{Q}, \mathrm{R}$ & $\begin{array}{c}49,50 \\
51\end{array}$ & 9.8 \\
\hline 30 & Drilling 08 hole diameter 25 & 15 & 0.6 & 67 & Welding Test (6) & 66 & 4.7 \\
\hline 31 & Drilling Q 8 Holes diameter 25 & 17 & 0.6 & 68 & $\begin{array}{l}\text { Welding } S, T, U, V \text { (part } \\
7 \text { ) }\end{array}$ & $\begin{array}{l}52,53 \\
54,55\end{array}$ & 11.6 \\
\hline 32 & $\begin{array}{l}\text { Drilling R } 3 \text { holes in diameter } \\
\qquad 25\end{array}$ & 18 & 0.2 & 69 & Welding Test (7) & 68 & 5.9 \\
\hline 33 & Drilling V 5 hole diameter 25 & 22 & 0.5 & 70 & Cleaning & 69 & 25 \\
\hline 34 & Component dimension Test $\mathrm{A}$ & $\begin{array}{c}1.2 \\
3\end{array}$ & 7.2 & 71 & Painting & 70 & 30 \\
\hline 35 & Component dimension Test B & 2 & 2.8 & 72 & Cutting of wooden blocks & 71 & 16.7 \\
\hline 36 & Component dimension Test $\mathrm{C}$ & 3 & 1.8 & 73 & Packaging & 71.72 & 29.8 \\
\hline 37 & Component Dimension Test D & 4 & 2.7 & & & & \\
\hline
\end{tabular}

Steel column production process at PT. XYZ has 73 work elements. Namely the cutting process, the drilling process, the dimensional test process, the welding process, the cleaning process, the painting process, and the packaging process. The steel column production process has 320 minutes, a production speed of 1.8 units per hour, a cycle time per station of 31.55 minutes, a minimum of 11 workers, and a service time of 31.6 minutes. The most effective and efficient improvement of track balance is using the Largest Candidate Rule Method. This method can produce 11 workstations with a line efficiency of $92.2 \%$, a balance delay of $7.8 \%$, and a smoothness index of 14.6 seconds. Figure 1 representative the comparing result of the effective method to calculate line balancing.

Table 2. Comparing Between three methods

\begin{tabular}{llcccc}
\hline No & \multicolumn{1}{c}{ Line Balancing } & $\begin{array}{c}\text { Number of } \\
\text { Workstation }\end{array}$ & $\begin{array}{c}\text { Line } \\
\text { efficiency }\end{array}$ & Balance delay & $\begin{array}{c}\text { Smoothness } \\
\text { index }\end{array}$ \\
\hline 1. & Initial Condition & 14 & $72.4 \%$ & $27.6 \%$ & 65.1 second \\
2. & Largest Candidate Rule & 11 & $92.2 \%$ & $7.8 \%$ & 14.6 second \\
3. & Killbridge and Wester Method & 12 & $84.5 \%$ & $15.5 \%$ & 35.1 second \\
4. & Ranked Positional Weight & 14 & $72.4 \%$ & $27.6 \%$ & 54.1 second \\
\hline
\end{tabular}

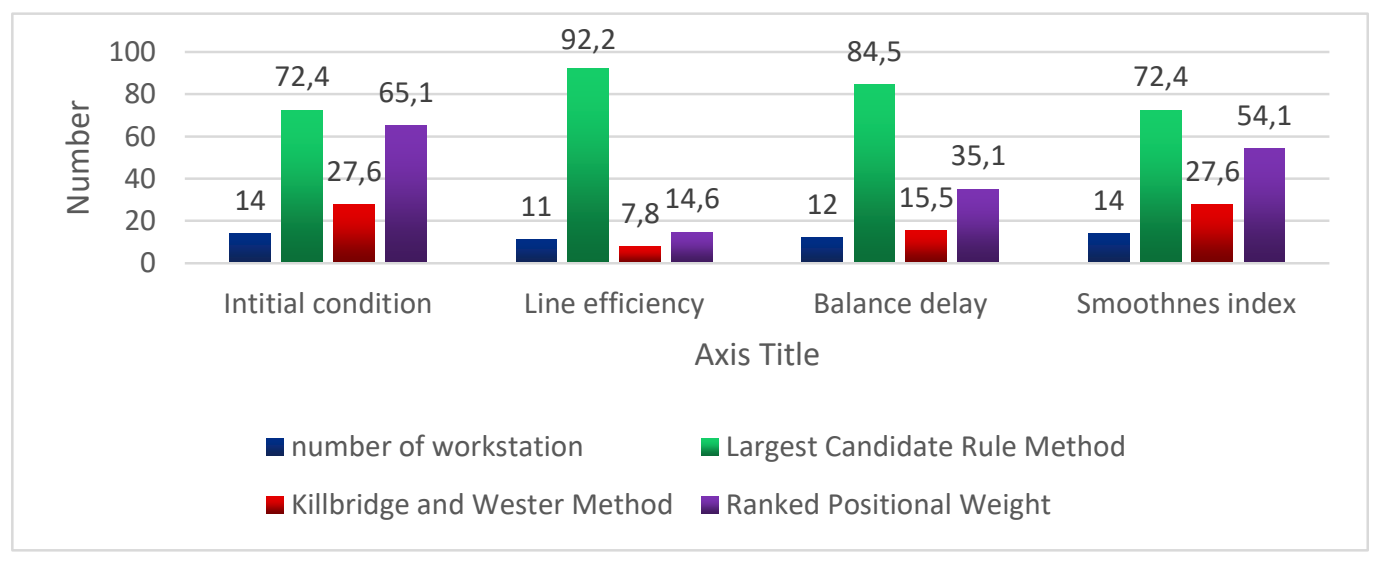

Figure 1. Line balancing result comparing 


\section{Conclusion}

Based on the balance improvement calculation, the most effective and efficient way to increase efficiency and reduce drag is to use the LCR Method. At the initial trajectory, the efficiency is $72.4 \%$; the smoothness index is 65.11 or the smoothness of production is very high. Meanwhile, the number of work stations is 14. After using the LCR Method in the production area, the company only has 11 workstations, it means the company can reduce 3 workstations. On the other hand, line efficiency is $92.2 \%$, balance delay is $7.8 \%$, and the smoothness index is 14.6 . It means that with a smoothness index reach14.6 seconds, companies can reduce the congestion bottleneck to $50.51 \%$.

There are several outputs of this research for the environment. I.e with decreasing the number of bottlenecks and increasing production efficiency causes a decreasing number of gas emissions. the value of high production efficiency causes the use of virgin material for more optimal product manufacturing. While the remaining products in the form of waste are also decreasing too.

\section{References}

Assauri, S. (2016). Management of Production Operations. Jakarta: PT. Grafido Persada.

Eko, A., Firman, A., \& Helmy, L. (2017). Improving Work flow Efficiency Using the RPW and Killbridge-Western Methods. Technical Dynamics, 10(1), 16-26.

Gasperzs, V. (2009). Production Planning and Inventory Control. Jakarta: PT. Gramedia Pustaka Utama.

Kriengkorakot, N., \& Pianthong, N. (2015). The Assembly Line Balancing Problem : Review articles. KKU Engineering Journal, 34(2), 133140

Niaz, M., \& Kazi, S. P. (2014). Assembly Line Balancing to Improve Productivity using Work Sharing Method in Apparel Industry. Global Journal of Research in Engineering: G Industrial ENgineering, 14(3), 1-11

Panchal, R. N., \& Awasare, A. D., \& Mulani, S. J. (2017). Methods of Solving Assembly Line Balancing Problems, International Journal of Engineering Technology, Management and Applied Sciences, 5 (7), 644- 648

Nasution, A. H. (2009). Production Planning and control. Yogyakarta: Graha Science.

Henky, K. S., Kuswara, S., \& Lusia. P. S. H. (2016). Perancangan Keseimbangan Lintasan Produksi Menggunakan Pendekatan Simulasi Dan Metode Ranked Positional Weights. Jurnal Teknik Industi, 11(1), 53-60. DOI: https://doi.org/10.12777/jati.11.1.53-60

Syukron, A., \& Kholil, M. (2014). Introduction to Industrial engineering. Yogyakarta: Graha Science.

Yudha, S. P. (2017). Improving the Efficiency of Plastic Box 260 Assemblies Using the Heuristic Method Approach. Proceedings of the MutiDisciplinary National Seminar Proceeding. Malang: Universitas Brawijaya. 